\title{
Motivation and Employees Performance in County Assembly of Mandera, Kenya
}

\author{
Hussein Adan Hassan ${ }^{1}$, DR. Priscilla Ndegwa ${ }^{2}$ \\ ${ }^{1}$ Correspondent Author, School of Business, Kenyatta University, Kenya \\ ${ }^{2}$ Lecturer, School of Business, Kenyatta University, Kenya
}

ABSTRACT

The introduction of devolution saw a great number of staff transferred from the national government to the County government. However, human resource management became a major challenge across all counties as most Counties lacked capacity. As a result there has been job dissatisfaction among employees of the county governments which can be detrimental to performance of both employees and county assembly at large. Hence there was need to implement strategies that can motivate employees in order to enhance their performance so as to get desired results from them. The general objective was to determine the effect of motivation on employee performance of in county assembly of Mandera, Kenya. The specific objectives were to: examine the effect of compensation package on performance of employees in Mandera County; to establish the effect of working environment on performance of employees in Mandera County; to assess the effect of job security on performance of employees in Mandera County; and to assess the effect of employee promotions on performance of employees in Mandera County. The study was informed by the equity theory, goal setting and the expectancy theory. The study adopted descriptive research design. The study population consisted of 150 employees in the County Assembly of Mandera. The population was grouped into departments of employees in the county Assembly. Stratified random sampling technique was used to select the sample. The study grouped the population into stratas, whereby from each stratum the study took a $30 \%$ sample. The sample size was 45 respondents. The study collected primary data through use of a questionnaire. The questionnaire had both closed and open-ended questions. The developed questionnaire was checked for its validity and reliability through pilot testing. The quantitative data was analyzed using descriptive and inferential statistics. The quantitative data was analyzed by using descriptive statistics which included frequency distribution tables and measures of central tendency (the mean), measures of variability (standard deviation) and measures of relative frequencies. The inferential statistics included a regression model which established the relationship between variables. Data was presented using tables, charts and graphs. The study findings show that compensation package, working environment, job security and employee promotions have an effect on performance of employees. The study concludes that compensation management can affect job satisfaction and employees organizational commitment, employees' will improve their performance if the problems identified during the research are tackled by the management and that Work environmental factors that influenced employee performance were physical environment factors, reward, management / leadership style, training and development and work-life balance. This study recommends that management and decision makers should endeavour to review compensation packages at various levels in order to earn employees' satisfaction, organizations should enhance flexibility of working environment, reduce work noise distraction and enhance supervisor's interpersonal relationship with subordinates. Organizations should have well recognized job pay package, job security, and 
reward system for their employees and organizations should be able to recognise employee who have done well at work, device mechanisms to retain and reward an employee for his years of service to the organization.

Keywords: Employee Motivation, Employees Performance, County Assembly of Mandera

DOI: 10.7176/ijcab.v3iIV.43, URN: urn:nbn:de:0000ijcab.v3iIV.432

\section{Cite this Article:}

Hassan, H., \& Ndegwa, P. (2019). Motivation and Employees Performance in County Assembly of Mandera, Kenya. International Journal of Current Aspects, 3(IV), 1-13. http://journals.ijcab.org/journals/index.php/ijcab/article/view/43

\section{INTRODUCTION}

Organizations in this dynamic globalized world are continuously trying to develop and motivate their employees to help to enhance performance with various Human Resource applications and practices (Shahzadi, Javed, Pirzada, Nasreen, \& Farida, 2014). Human resource (employees) plays a very important role in the development of the organizations. Human Resource Management focuses on personnel related areas such as job design, resource planning, performance management system, recruitment, selection, compensations and employee relations (Dechev, 2010). All organizations want to be successful, even in current environment which is highly competitive. Therefore, organizations irrespective of size and market strive to retain the best employees, acknowledging their important role and influence on organizational effectiveness. In order to overcome these challenges, organizations should create a strong and positive relationship with its employees and direct them towards task fulfilment (Dobre, 2013). Employees are the bedrock of every business; and to be successful, a business requires the commitment and sacrifice of employees. Employees are particularly important participant in the formulation of the image that customers get in relation to the service outcome (Ibrahim \& Brobbey, 2015). Because of the importance of this interaction with the customer, employees have to communicate effectively the quality standards of their organisation to new starters. To successfully market or sell the company's services or products, the company must first and foremost target employees. Employees are therefore the first customers of every organization. Once the company is able to identify employees' needs, then they will be motivated to work effectively to achieve the goals of the organization (Ibrahim \& Brobbey, 2015).

Reward management system is the highly used practice for t.he enterprises to achieve the desired motivation goals (Güngör, 2011). According to Barber and Bertz (2012), reward management system helps the organizations to attract, capture, retain and motivate employees with high potential and in return get high levels of performance. Reward management system consists of both extrinsic and intrinsic rewards; where former involves financial rewards (salary, bonus etc) and the later includes non-financial rewards like recognition, security, title, promotion, appreciation, praise, decision making involvement, flexible working hours, workplace comfort ability, feedback, work design, social rights etc (Yang, 2008). Adequate levels of earnings, safe and humane conditions of work and access to some minimum social security benefits are also the major qualitative dimensions of employment which enhance quality of life of workers, motivation and their productivity (Venugopal et al., 2011). Organization tries to satisfy and motivate their employees to get better result (Dechev, 2010). Diversity at workplace has 
provided managers with substantial magnitude of problems, the big difference between employees in every organization means that there is no best way to deal with such problem. What motivates some employee to perform very well may be discouraging to other employee, therefore it poses a big challenge to present day managers (Obiekwe, 2016). Employee motivation is considered as a force that drives the employees toward attaining specific goals and objectives of the organization. Now days, it is one of the sizzling issue in organizations since every wants to make best use of their financial and human resources (Shahzadi et al., 2014).

Motivation is an area that is extensively researched in Africa as organisations are seeking various ways to motivate employees. In Ghana, Ibrahim and Brobbey (2015) established that the general problems mostly inherent in organizations and institutions in Ghana are low salaries and wages, irregular promotional structures, lack of recognition of workers achievements and other poor conditions of service. They indicated that motivation is one of the factors that affect employees' performance. Motivation improves employees' level of efficiency, helping employees to meet their personal goals, employee satisfaction, and helping employees bond with the organization. In Kenya, studies have shown that motivation enhances employee performance. For instance Wanjihia (2016) established that a good salary and compensation package, and a yearly bonus would greatly motivate employees in addition to other non-monetary rewards such as gift vouchers and paid vacations for them. In regard to achievement and recognition as motivating factors, it was established that employees greatly value these motivators and especially when done publicly or in the presence of their colleagues. It concluded that reward, achievement and recognition, and, performance appraisal and feedback have a great influence on employee motivation and consequent performance at the work place. Employee motivation is defined as the willingness to exert high levels of effort toward organizational goals, conditioned by the effort's ability to satisfy some individual need. To engage in the practice of motivating employees, employers must understand the unsatisfied needs of each of the employee groups (Ramlall, 2004). Helepota (2005) also defined motivation as a person participation in achieving the desired results of an organization. Motivation is an important issue in any organization because it is involved in energizing or initiating human behaviour, directing and channelling that behaviour and sustaining and maintaining it (Steers \& Porter, 1987). Motivated employees are highly involved and engaged in their job and try to make their performance best. Motivated employees are those who work according to the clearly define goals and take their actions to achieve that goals (Vansteenkiste, 2007).

Employee motivation is very important for organizations as every concern requires physical, financial and human resources to accomplish the goals. It is through motivation that the human resources can be utilized by making full use of it (Abbah, 2014). This can be done by building willingness in employees to work. This will help the enterprise in securing best possible utilization of resources (Rothberg, 2005). It results into increase in productivity, reducing cost of operations, and improving overall efficiency. According to a study conducted by Grant (2008), motivation imposes employee outcomes for instance performance and productivity. He also established that motivated employees are more oriented towards autonomy and are more selfdriven in contrast to less motivated employees. Further, motivated employees are highly engaged and involved in their work and jobs and are more willing to take responsibilities (Kuvaas \& Dysvik, 2009). Herzberg (1987) indicated that in order to motivate employees through performance appraisal, the system should be used for reward and recognition. There is no doubt, 
however, that extrinsic incentives can boost performance (Herzberg, 1987). Goal-setting theory (Locke \& Latham, 1979) states that motivation and performance are higher when individuals are giving specific goals, when goals are difficult but accepted and when there is feedback on performance. Motivation and performance will improve if people have challenging but agreed goals and receive feedback (Armstrong, 2006). There are two measures of motivation that is, monetary and non-monetary incentives which can be offered by to employees by the management. According to Torrington, Hall and Taylor (2008) both monetary and non-monetary positive motivators foster team spirit and include financial compensation, recognition, responsibility, and advancement. Managers, who recognize the "small wins" of employees, promote participatory environments, and treat employees with fairness and respect will find their employees to be more highly motivated. In this study, both monetary and non-monetary indicators will be employed as measures of employee motivation. These will include: financial compensation, employee working environment and employee recognition. Performance of the employee is considered as what an employee does and what he doesn't do. Employee performance involves quality and quantity of output, presence at work, accommodative and helpful nature and timeliness of output. According to the results of the study conducted by Yang (2008) on individual performance showed that performance of the individuals cannot be verified. Similarly he asserts that organizations can use direct bonuses and rewards based on individual performance if employee performance is noticeable.

On the other hand, Yazici (2008) revealed that moral and productivity of employees is highly influenced by the effectiveness of performance of an organization and its reward management system. To satisfy customers, firms do much effort but do not pay attention on satisfying employees. But the fact is that customer would not be satisfied until and unless employees are satisfied. Because, if employees are satisfied, they will do more work therefore ultimately customers will be satisfied (Ahmad et al., 2012). Employee performance is actually influenced by motivation because if employees are motivated then they will do work with more effort and by which performance will ultimately improve (Azar \& Shafighi, 2013). Mandera County is located in the North Eastern part of Kenya and it covers an area of $25,991.5 \mathrm{Km} 2$ and. It borders Ethiopia to the North, Somalia Republic to the East, and Wajir County to the South and West (GoK, 2013). The county is divided into six administrative sub-counties namely: Banissa, Lafey, Mandera West, Mandera East, Mandera North and Mandera Central. These sub-counties are further sub-divided into 22 divisions, 97 locations and 141 sub-locations. The county has six parliamentary constituencies namely: Mandera East, Banissa, Mandera West, Lafey, Mandera North and Mandera South. Moyale town is the county headquarters. With the introduction of devolution, a great number of staff were transferred from the national government to the County government. Some of the devolved sectors include: health, agriculture, water, among others. Human resource management has been cited as a major challenge across all counties as most Counties lacked capacity. Mandera County have also employed other more staff to enhance service delivery in the County. This study sought to determine the effect of motivation on performance of employee in Mandera County.

\section{STATEMENT OF THE PROBLEM}

There are challenges of employee motivation, capacity and performance in Mandera County (Yussuf, 2016). The County have not been able to attain its revenue collection targets. Controller of Budget report (2017) showed that Mandera County was among those Counties that generated 
the least amounts of revenue, vis-à-vis the revenue targets in the 2016/17 financial year. There is also poor quality service delivery, which is coupled with poor performance of employees who do not meet deadlines or timelines in terms of meeting targets, since the county lack qualified personnel, as most qualified personnel opt to work in other areas where there is good working conditions and security, hence the need to improve staff capacity building to boost quality service delivery (Yussuf, 2016). These issues have been of concern to the human resource management. Besides these challenges, Mandera County has had rampant insecurity issues which make a lot of personnel shy away from working in the area hence there is high turnover of employees. There are also poor environmental conditions such as lack of good accommodation, lack of access to transport and emergency services (Aburo, 2016). There is job dissatisfaction by employees of the county government which can be detrimental to both employees and County Assembly at large. Since devolution is still a new concept in Kenya and that the employees working in the devolved functions have already shown resentment on devolution, it is important to motivate the employees (Alande, 2014). Mandera County needs to understand and implement motivational strategies that will enhance the performance of employees in order to get desired results from them.

A review of the existing literature shows that Mwangi (2014) conducted a study on the effect of compensation on employee motivation in Chloride Exide. This study was however conducted on a profit making corporate as compared to the proposed study which will be conducted in the county government. In addition, the study only looked at compensation of employees while the proposed study will be looking at more diverse employee motivation variables (both monetary and non-monetary). Omollo and Oloko (2015) also conducted a study on effect of motivation on employee performance of commercial banks in Kenya while Waiyaki (2017) conducted a study effect of motivation on employee performance, with a focus on Pam Golding properties limited, Nairobi. These two studies were conducted on employees of profit making companies, and not on county governments. The variables studies in these two studies were also different from the ones of the proposed study. The findings therefore cannot be generalised to this study since there are conceptual and contextual gaps. From the review of the above studies, none has looked at motivation of employees in the county assemblies. It is against this backdrop therefore that the study sought to examine the effects of motivation on performance of employees in county assembly in Mandera County.

\section{OBJECTIVES OF THE STUDY}

The general objective was to determine the effect of motivation on employee performance in county assembly of Mandera, Kenya.

The study was guided by the following specific objectives:

i. To examine the effect of compensation package on performance of employees in Mandera County.

ii. To establish the effect of working environment on performance of employees in Mandera County.

iii. To assess the effect of job security on performance of employees in Mandera County.

iv. To assess the effect of employee promotions on performance of employees in Mandera County. 


\section{THEORETICAL REVIEW}

This section discuses the theories that were critical in guiding the study. The study was informed by the equity theory, goal setting and the expectancy theory.

\subsection{Equity Theory}

This theory was first developed in 1963 by Stacy Adams. Equity theory attempts to explain relational satisfaction in terms of perceptions of fair/unfair distributions of resources within interpersonal relationships. Adams (1965) asserted that employees seek to maintain equity between the inputs that they bring to a job and the outcomes that they receive from it against the perceived inputs and outcomes of others. Griffin and Moorhead (2012), also state that employees seek to be fairly treated. Employee perception on fairness and equity is based on a comparison between themselves (Griffin \& Moorhead, 2012). In addition, employees compare the remuneration and rewards they receive with those offered in other institutions. Based on the results from comparisons, employees can either be motivated or de-motivated when performing tasks (Pride et al., 2012; Griffin \& Moorhead, 2012). This can be attributed to the fact that employees will compare their input and their compensation. On the other hand, Dubrin (2008) states that employees will put in the greatest effort in their tasks if they expect the effort to lead to performance that in turn will lead to a reward. These employees are motivated by what they expect will be the positive consequences of their efforts. The consequences of employees efforts are realized through assessments of their tasks through performance appraisals. Griffin and Moorhead (2012) highlight the following as managerial lessons from equity theory: it is necessary for all employees to understand the reward system; employees perceive rewards differently, and employees will always conduct equity analysis.

Leete (2000) highlights the utilization of equity theory through a study conducted on motivation measures utilized by both profit and non-profit making institutions. Wage and reward equity is positively related with employee motivation and satisfaction (Leete, 2000; Tortia, 2008). The lack of employee equity and fairness leads to absenteeism and high turnover rate (Geurts, Schaufeli \& Rutte, 1999). Ryan (2012) describes one limitation of equity theory as it does not highlight how institutions should handle equity inconsistencies. The equity theory will help understand how employees perceive their inputs that they bring to a job and the outcomes that they receive from it. They also compare these against the perceived inputs and outcomes of others. For instance, the employees in County Assembly of Mandera will compare their compensation package against their inputs, and may also compare these packages with what is offered to employees of other County Assemblies. Employees who feel they are being treated inequitably may put less effort into their jobs; ask for better treatment and/or rewards; find ways to make their work seem better by comparison; transfer or quit their jobs. The equity theory makes a good point that people behave according to their perceptions. This means that employees will put effort into their jobs based on how good they are motivated.

\subsection{Goal-Setting Theory}

The Goal Setting Theory was developed by Edwin A. Locke in 1968, in order to explain human actions in specific work situations. This theory states that goal setting is essentially linked to task performance. It states that specific and challenging goals along with appropriate feedback contribute to higher and better task performance (Locke \& Latham, 1979; Locke \& Latham, 2006). According to this theory, motivation and performance are higher when individuals are 
giving specific goals, when goals are difficult but accepted and when there is feedback on performance. Goals have a pervasive influence on employee behavior and performance in organizations and management practice (Locke \& Latham, 2002). According to Locke and Latham $(2002,2006)$ there are five goal setting principles that can improve our chances of success, these are: Clarity, challenge, commitment, feedback and task complexity. In setting clear goals, Locke and Latham (2002) argue that when one goals are clear, they know what they're trying to achieve. They can also measure results accurately, and know which behaviors to reward.

Motivation and performance will improve if people have challenging but agreed goals and receive feedback (Armstrong, 2006). The performance benefits of challenging, specific goals have been demonstrated in hundreds of laboratory and field studies (Locke \& Latham, 1990, 2002). Such goals positively affect the performance of individuals (Baum \& Locke, 2004), groups (O’LearyKelly, Martocchio, \& Frink, 1994), organizational units (Rogers \& Hunter, 1991), as well as entire organizations (Baum, Locke, \& Smith, 2001); and over periods as long as 25 years (Locke \& Latham, 2002). Locke and Latham (2002) further argues that by providing direction and a standard against which progress can be monitored, challenging goals can enable people to guide and refine their performance. Latham (2004) asserts that specific goals can boost motivation and performance by leading people to focus their attention on specific objectives, increase their effort to achieve these objectives (Bandura \& Cervone, 1983), persist in the face of setbacks (Latham \& Locke, 1975), and develop new strategies to better deal with complex challenges to goal attainment (Wood \& Locke, 1990). Through such motivational processes, challenging goals often lead to valuable rewards such as recognition, promotions, and/or increases in income from one's work (Latham \& Locke, 2006). This provides self-satisfaction, achieving goals often also increases organizational commitment (Tziner \& Latham, 1989), which in turn positively affects organizational citizenship behavior (Organ, Podsakoff, \& Mackenzie, 2006), negatively affects turnover (Wagner, 2007), and increases the strength of the relationship between difficult goals and performance (Locke \& Latham, 2002). Goal setting theory is critical in informing this study since it explains how organizations can improve employees performance by not only enhancing motivation, but also through increasing and improving the feedback quality. The goals indicate and give direction to an employee about what needs to be done and how much effort are required to be put in; which provides self-satisfaction and commitment which in turn positively affects the performance of employees.

\subsection{Expectancy Theory}

The expectancy theory was proposed by Victor Vroom in 1964. Vroom (1964) stresses and focuses on outcomes, and not on needs unlike Maslow and Herzberg. The theory states that the intensity of a tendency to perform in a particular manner is dependent on the intensity of an expectation that the performance will be followed by a definite outcome and on the appeal of the outcome to the individual (Vroom, 1964; Lawler, Porter \& Vroom, 2009). The Expectancy theory states that employee's motivation is an outcome of how much an individual wants a reward (Valence), the assessment that the likelihood that the effort will lead to expected performance (Expectancy) and the belief that the performance will lead to reward (Instrumentality) (Vroom, 1964). In short, Valence is the significance associated by an individual about the expected outcome. It is an expected and not the actual satisfaction that an employee expects to receive after achieving the goals. Expectancy is the faith that better efforts will result 
in better performance. Expectancy is influenced by factors such as possession of appropriate skills for performing the job, availability of right resources, availability of crucial information and getting the required support for completing the job (Scholl, 2002).

Expectancy Theory is based on self-interest individual who want to achieve maximum satisfaction and who wants to minimize dissatisfaction. This theory stresses upon the expectations and perception; what is real and actual is immaterial. It emphasizes on rewards or pay-offs. It focuses on psychological extravagance where final objective of individual is to attain maximum pleasure and least pain. Vroom was of view that employees consciously decide whether to perform or not at the job. This decision solely depended on the employee's motivation level which in turn depends on three factors of expectancy, valence and instrumentality (Lawler et al., 2009). This theory helps understand that this employee's motivation is determined by a number of factors, which includes: how much an individual wants a reward, the assessment that the likelihood that the effort will lead to expected performance and the belief that the performance will lead to reward. Based on this theory, the extent or level of performance of employee performance in county assembly of Mandera solely depended on the employee's motivation. The theory emphasizes on rewards or pay-offs as key motivators.

\section{CONCEPTUAL FRAMEWORK}

The conceptual framework represents and interprets the underlying concepts/variables of the research study. It diagrammatically shows the relationship between variables in the study. In this study the independent variables were: compensation package, working environment, job security and employee promotions while the dependent variable was employee performance. The conceptual frame work is presented in the Figure 1 below.

\section{Independent Variables}

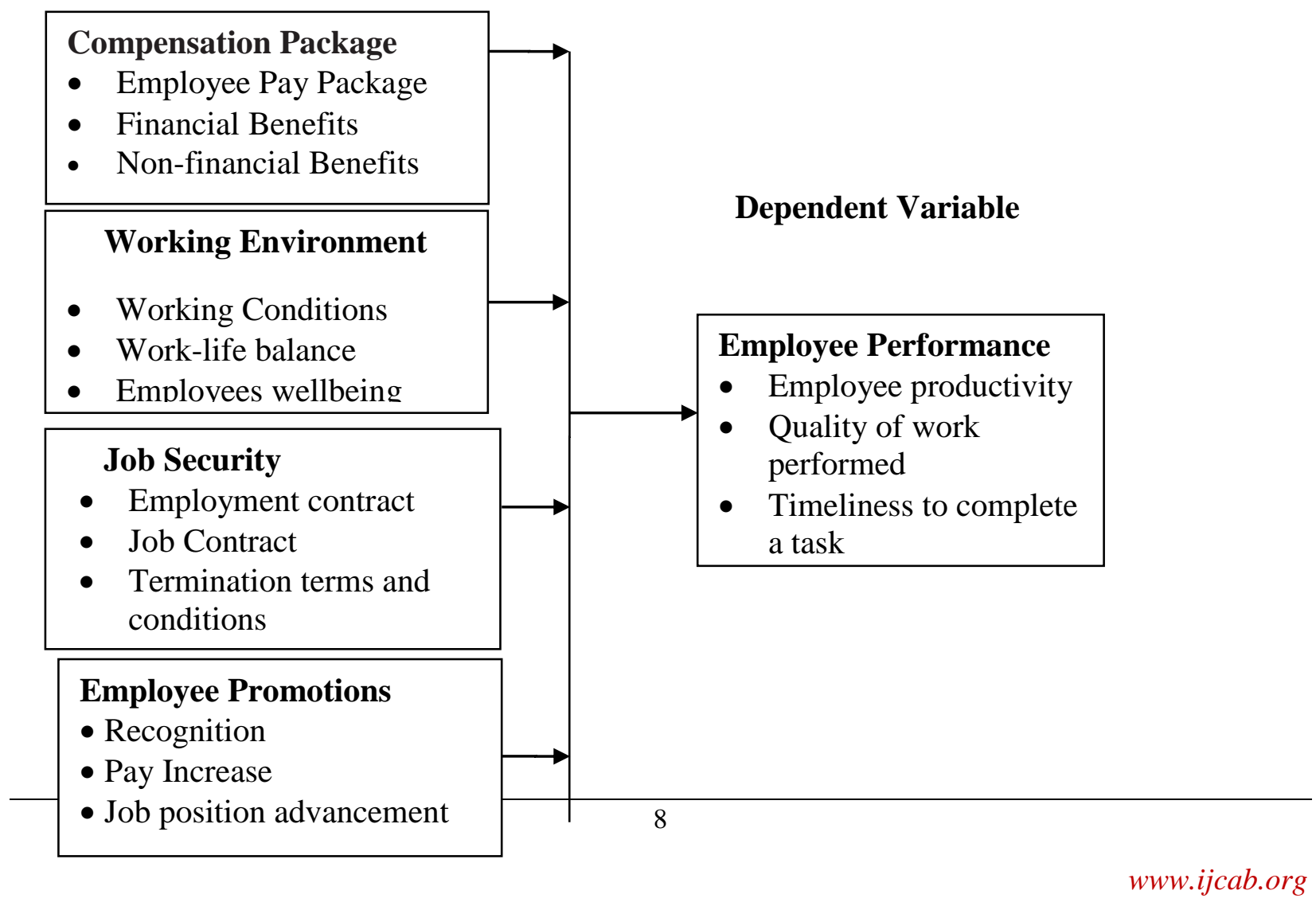




\section{Figure 1: Conceptual Framework}

\section{RESEARCH METHODOLOGY}

The study adopted descriptive research design. The descriptive design was appropriate for this study since it would help in collecting data in order to answer the questions of the current status and describe the nature of existing conditions of the subject under study. Descriptive research design also facilitated the use of a questionnaire to collect both quantitative and qualitative data for the study. Its advantage was that it was used extensively to describe behavior, attitude, characteristic and values (Mugenda \& Mugenda, 2003). The study targeted the employees of County Assembly of Mandera. There were 150 employees in the county Assembly of Mandera, according to the records in the human resource department. The population was grouped into departments of employees in the County Assembly. Stratified random sampling technique was used to select the sample. The data collected by the questionnaire was edited, coded, entered into Statistical Package for Social Sciences (SPSS) which also aided in the data analysis. This study was expected to generate qualitative and quantitative data. The quantitative data was analyzed using descriptive and inferential statistics. Qualitative data was analyzed based on the content matter of the responses. The qualitative data was generated from the open ended questions and was categorized in themes in accordance with research objectives and reported in narrative form along with quantitative presentation. Responses with common themes or patterns were grouped together into coherent categories. Both descriptive and inferential statistics were adopted for the study. The quantitative data was analyzed by using descriptive statistics which included frequency distribution tables and measures of central tendency (the mean), measures of variability (standard deviation) and measures of relative frequencies. The inferential statistics included a Spearman correlation and regression model which established the relationship between variables. Pearson $r$ was used in this study since the data measured in the Likert scale and Pearson's correlation coefficient technique is recommended as being the most appropriate for determining relationships. Data was presented using tables, charts and graphs.

\section{STUDY FINDINGS}

Inferential statistics in this study were used to describe and make inferences about the population under study through the use of a random sample of the larger population. This study used the correlation analysis to measure the strength of the association between the independent and dependent variables as well as determine the direction of the relationship if any.

Table 1: Correlation Analysis

\begin{tabular}{|l|l|l|l|l|l|}
\hline & Performance & $\begin{array}{l}\text { Compensation } \\
\text { Package }\end{array}$ & $\begin{array}{l}\text { Working } \\
\text { Environment }\end{array}$ & $\begin{array}{l}\text { Job } \\
\text { Security }\end{array}$ & $\begin{array}{l}\text { Promotional } \\
\text { Activities }\end{array}$ \\
\hline Performance & 1 & & & & \\
\hline Compensation Package & 0.73 & 1 & & & \\
\hline Working Environment & 0.82 & 0.895 & 1 & & \\
\hline Job Security & 0.74 & 0.49 & 0.347 & 1 & \\
\hline Promotional Activities & 0.72 & 0.75 & 0.66 & 0.241 & 1 \\
\hline
\end{tabular}


From the correlation analysis table above, there is a high positive correlation between performance of employees and the motivational strategies employed by the Mandera county assembly management. The compensation package offered and performance has a person correlation of 0.73 , the nature of the working environment showed a positive relationship with performance $(\mathrm{r}=0.82)$ as well as job security and nature of promotional activities offered to staff members $(\mathrm{r}=0.74,0.72)$.

Regression analysis was used to assess the relationship between an outcome or dependent variable and one or more risk factors or confounding variables in this case the independent variables. Findings are presented in Table 1, 2 and 3.

Table 2: Model Summary

\begin{tabular}{|c|c|c|c|c|c|c|c|c|c|c|}
\hline \multirow[b]{2}{*}{ Model } & \multirow[b]{2}{*}{$\mathrm{R}$} & \multirow[b]{2}{*}{ R Square } & \multirow[b]{2}{*}{$\begin{array}{l}\text { Adjusted } \\
\text { Square }\end{array}$} & \multirow[b]{2}{*}{$\mathrm{R}$} & \multirow[b]{2}{*}{$\begin{array}{l}\text { Std. Error of the } \\
\text { Estimate }\end{array}$} & \multicolumn{5}{|c|}{ Change Statistics } \\
\hline & & & & & & $\begin{array}{l}\mathrm{R} \text { Square } \\
\text { Change }\end{array}$ & $\begin{array}{l}\mathrm{F} \\
\text { Change }\end{array}$ & df1 & df2 & $\begin{array}{l}\text { Sig. F } \\
\text { Change }\end{array}$ \\
\hline 1 & $.798^{\mathrm{a}}$ & .636 & -.628 & & .18279 & .089 & .730 & 4 & 30 & .578 \\
\hline
\end{tabular}

a. Predictors: (Constant), composite promotion, composite job security, composite work environment, composite compensation

From the regression the regression model is significant as the coefficient of determination Rsquare is 0.636 depicting that most of the variations about $64 \%$ are explained by the model. This shows that the level of performance of the employees is highly dependent on the level of motivational strategies employed.

Table 3: ANOVA ${ }^{\mathrm{a}}$

\begin{tabular}{|ll|l|l|l|l|l|}
\hline & & & Mean & & \\
Model & & Sum of Squares & $\mathrm{df}$ & Square & $\mathrm{F}$ & Sig. \\
\hline 1 & Regression & 1.002 & 4 & .033 & 7.30 & $.00578^{\mathrm{b}}$ \\
& Residual & 0.0098 & 30 & .0024 & & \\
& Total & 1.1000 & 34 & & & \\
\hline
\end{tabular}

a. Dependent Variable: composite employee performance

b. Predictors: (Constant), composite promotion, composite job security, composite work environment, composite compensation

To show this the $\mathrm{F}(4,30)=7.0, \mathrm{p}<0.05$, indicating the model is a good fit to the data set. The regression model to this relationship is given by the following equation.

$F(X)=\beta 0+\beta 1 \times 1+\beta 2 \times 2+\beta \times 3+\beta 4 \times 4+£$

Table 4.12 Coefficients ${ }^{\mathrm{a}}$

\begin{tabular}{|c|c|c|c|c|c|c|c|}
\hline \multirow[b]{2}{*}{ Model } & \multicolumn{2}{|c|}{$\begin{array}{l}\text { Unstandardize } \\
\text { d Coefficients }\end{array}$} & \multirow{2}{*}{$\begin{array}{l}\text { Standardiz } \\
\text { ed } \\
\text { Coefficient } \\
\text { s } \\
\text { Beta }\end{array}$} & \multirow[b]{2}{*}{$t$} & \multirow[b]{2}{*}{ Sig. } & \multicolumn{2}{|c|}{$\begin{array}{l}95.0 \% \\
\text { Confidence } \\
\text { Interval for B }\end{array}$} \\
\hline & B & $\begin{array}{l}\text { Std. } \\
\text { Error }\end{array}$ & & & & $\begin{array}{l}\text { Lower } \\
\text { Bound }\end{array}$ & $\begin{array}{l}\text { Upper } \\
\text { Bound }\end{array}$ \\
\hline
\end{tabular}


International Journal of Current Aspects, Volume 3, Issue IV, 2019, PP 1-13, ISSN 2616-6976 [i]CAB

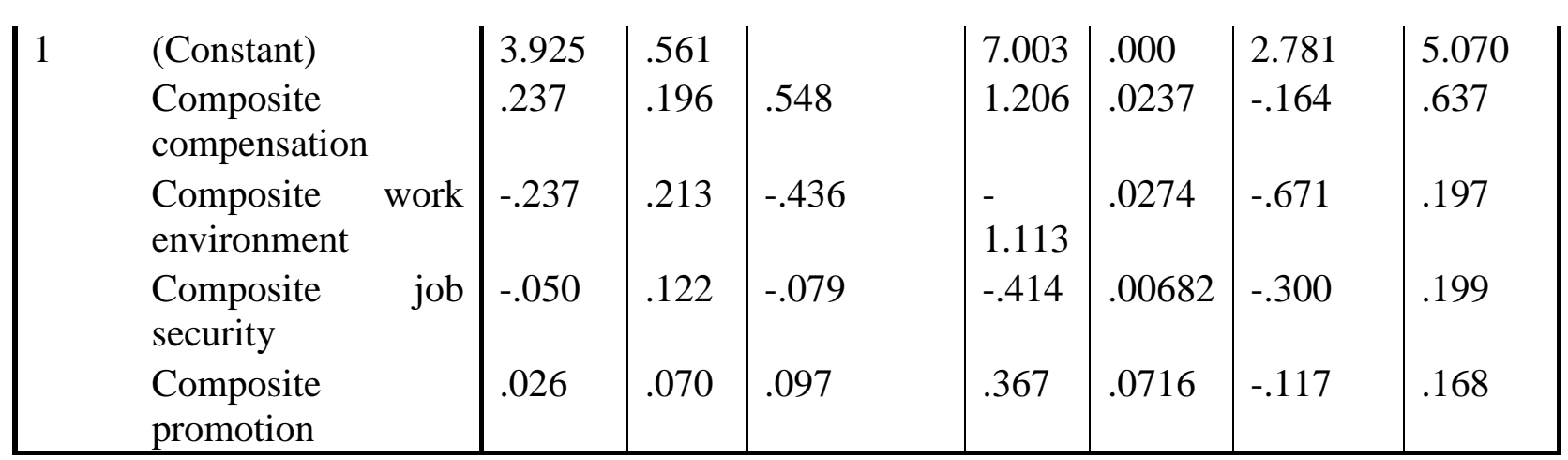

a. Dependent Variable: composite performance

From the regression model representing the relationship between performance of employees and the motivational strategies employed namely compensation package, nature of working environment, job security and the level of promotions offered will be given as below. $\mathrm{F}(\mathrm{X})=$ 3.925+0.37(Compensation package)-0.237(Working Environment conditions)-0.050(Job Security) +0.026(Promotional Activities). Further from the all the independent variables are statistically significant since all the coefficients are not equal to zero. The $t$ statistics with the sig value of less than 0.005 in all cases signify this statistical significance.

\section{CONCLUSIONS}

The study concludes that compensation package has an effect on performance of employees. Compensation management can affect job satisfaction and employees organizational commitment and that Organizations can use employee compensation as a method for enhancing employee's motivation and their commitment with the organization. The study concludes that working environment has an effect on performance of employees in Mandera County. Employees' will improve their performance if the problems identified during the research are tackled by the management. It was concluded that job security has an influence on performance of employees. Insecurity was negatively correlated with job performance and positively with absenteeism. However, work related attitudes moderated only the effect of job insecurity on job performance but not on absenteeism. The study concludes that employee promotions have an effect on performance of employees. Work environmental factors that influenced employee performance were physical environment factors, reward, management / leadership style, training and development and work-life balance.

\section{RECOMMENDATIONS}

This study recommends that management and decision makers should endeavour to review compensation packages at various levels in order to earn employees' satisfaction and prevention of high labour turnover among the members of staff. Based on the research findings, the study recommended that organizations should enhance flexibility of working environment, reduce work noise distraction, enhance supervisor's interpersonal relationship with subordinates, presence of job aid, the use of performance feedback and improve of work incentives in the organization so that to motivate employees to perform their job. The study recommended that organizations should have well recognized job pay package, job security, and reward system for their employees since this is thought to improve on performance and productivity. The study also recommended that organizations should be able to recognise employee who have done well at 
work,device mechanisms to retain and reward an employee for his years of service to the organization and to build loyalty, enhance morale and a sense of belongingness in the employee.

\section{REFERENCES}

Abbah, M.T. (2014). Employee Motivation: The Key to Effective Organizational Management in Nigeria. IOSR Journal of Business and Management (IOSR- JBM), 16 (4), 1-8.

Aburo, V. Y. (2016). Effects of Under Development in Mandera County Kenya. Unpublished Thesis. United States International University - Africa.

Ahmad, M. B., Wasay, E., \& Malik, S. U. (2012). Impact of Employee Motivation on Customer Satisfaction: Study of Airline Industry in Pakistan, Interdisciplinary Journal of Contemporary Research in Business, 4(6), 531-539.

Alande, J. O. (2014). Role of Human Resource Management in Devolution of Counties in Kenya. Jomo Kenyatta University of Agriculture and Technology, Nairobi, Kenya. http://journals.jkuat.ac.ke

Armstrong, M., (2006). A Handbook of Human Resource Management Practice, London: Kogan Page Limited.

Controller of Budget report (2017). Revenue targets in the 2016/17 financial year.

Dechev, Z. (2010). Effective Performance Appraisal - a study into the relation between employer satisfaction and optimizing business results. Faculty of Economics of Business Department of Economics

Dobre, O. (2013). Employee motivation and organizational performance. Review of applied socio-Economic Research, 5(1), 53-60.

Helepota, H. A. (2005). Motivational Theories and their application in construction, Cost Engineering, 47(3), 14-35.

Herzberg, F.I., (1987). One More Time: How Do You Motivate Employees?, Harvard Business Review, 65 (5), 109-120

Ibrahim, M. \& Brobbey, V.A. (2015). Impact of Motivation on Employee Performance the Case of Some Selected Micro Finance Companies in Ghana. International Journal of Economics, Commerce and Management, 3(11), 1218-1236.

Kuvaas, B. and Dysvik, A. (2009), "Perceived nvestment in Employee Development, intrinsic Motivation and Work Performance', Human Resource Management Journal, 19(3), 217-236.

Barber, A.E., Dunham, R. and Formisano, R.A. (2012), "The impact of flexible benefits on Employee satisfaction: a field study", Personnel Psychology, 45, 55-75.

Latham, B. (2007). Sampling: What is it?. Retrieved from http://webpages.acs.ttu. edu/rlatham/Coursework/5377(Quant))/Sampling__Methodology_Paper.pdf.

Locke, E. A. and Latham, G. P., (1979), Goal Setting-A Motivational Technique That Works, Organizational Dynamics, 8(2), 68-80.

Locke, E. A., \& Latham, G. P. (2002). Building a practically useful theory of goal setting and task motivation: A 35year odyssey. American Psychologist, 57, 705717.

Locke, E.A.; Latham, G.P. (2006). "New directions in goal-setting theory". Current Directions in Psychological Science 15 (5), 265-268.

Mugenda, O. M. \& Mugenda A. G. (2003), Research Methods. Quantitative and Qualitative Approaches, Nairobi: Acts Press), 72. 
Ramlall, S. (2004). A review of employee motivation theories and their implications for employee retention within organizations. The Journal of American Academy of Business, Cambridge, 5 (1/2), 52-63.

Rothberg, G., (2005, Fourth Quarter). The Role of Idea in the Managers Workplace: Theory and Practice. Pakistan Management Review, 42 (4), 48-73.

Shahzadi, I., Javed, A., Pirzada, S. S., Nasreen, S., \& Farida, K. (2014). Impact of Employee Motivation on Employee Performance. European Journal of Business and Management, 6 (23), 159-176.

Steers, R. M. and Porter, L. W., (1987), Motivation and Work Behaviour and Performance, New York: Scott Foresman and Company.

Torrington, D., Hall, L. \& Taylor, S. (2008). Human Resource Management, (7th ed.). Harlow: Prentice Hall.

Venugopa, L, P., Bhaskar, T., \& Usha, P. (2011) Employee Welfare Activities With Respective Measures in Industrial Sector - A Study on Industrial Cluster at Chittor District. International Journal of Research in Commerce, It \& Management. 1(6).

Yazici, N. K., (2008). “The Effect of Reward System Applications on Employee Performance in Service Sector', Marmara University, Institute of Social Sciences, Master Thesis. Yang, H. (2008), "Efficiency Wages and Subjective Performance Pay", Economic Inquiry, 46(2), 179-196.

Yussuf, A. A. (2016). Challenges in the Strategy Implementation of Mandera County Government. Unpublished Research Project, University of Nairobi, Kenya.

This is an open-access article published and distributed under the terms and conditions of the $(\mathrm{cc}) \mathrm{Er}$ Creative Commons Attribution 4.0 International License of United States unless otherwise stated. Access, citation and distribution of this article is allowed with full recognition of the authors and the source.

Authors seeking to publish with an International Peer Reviewed Journal should consider www.ijcab.org by writing to the Editor at editor@ijcab.org. The articles must be quality, value adding and meet originality test. 